\title{
ELITE CIRCULATION IN THE HUNGARIAN CULTURAL ELITE. A CASE STUDY OF THEATRES
}

\author{
LUCA KRISTÓFl
}

\begin{abstract}
Recent literature on Hungary seems to be conclusive about the fact that elite consensus has collapsed and democracy is backsliding towards autocracy because of the elites' norm-breaking behavior (Lengyel 2014; Bozóki 2015; Kristóf 2015). It is also recognized that the governmental elite has been gaining influence and power over other elite groups. Since 2010, the ruling political elite has reallocated property rights, public and EU funds to new loyal economic elites who are much more closely controlled by the political elite (Csillag and Szelényi 2015). Though less the focus of scientific inquiry, a similar process has occurred in the field of culture: the incumbent political elite aspires to eliminate old cultural structures in order to redistribute cultural positions and resources. This case study is based on interviews with leaders of theatres, cultural policy-makers and the most renowned actors and directors in the Hungarian theatrical field. Interviews are supplemented with discourse analysis about the circulation of the theatre elite, and a public opinion poll $(N=500)$ about the reputation of two emblematic figures of the old and the new elite.
\end{abstract}

KEYWORDS: cultural field, reputational elite, positional elite, conflicts, circulation

\section{THEORETICAL BACKGROUND}

Classical elite theory differentiates between two elite types (Pareto, 1942). The governing elite exercises concrete governmental power, or control over it (e.g. as a member of parliament). The non-governing elite is composed

\footnotetext{
1 Luca Kristóf is research fellow at the Centre for Social Sciences, Hungarian Academy of Sciences, e-mail: kristof.luca@tk.mta.hu. This work was supported by the Bolyai scholarship of the Hungarian Academy of Sciences
} 
of powerful and privileged groups whose members have no overt political positions but who exercise influence over political processes and the governing elite itself. Members of the cultural elite can be located in both categories. Politicians who deal with cultural affairs and institutional decision-makers in cultural policy belong to the governing elite. Other culturally influential actors, such as leading artists or scientists who have great reputations but are not formally involved in decision making, belong to the non-governmental elite.

Hence, the cultural elite cannot be defined only by positional criteria. Restricting the elite to the holders of top cultural positions would be inconsistent with the structure of the cultural field. Field theory assigns an outstanding role to reputation. According to Bourdieu, reputation measures the state of competition for goods in a social field dominated by cultural capital (Bourdieu 1996, 1983). In other words, it shows the position of an individual within the field. Several authors conclude that reputation is an essential prerequisite of a proper functioning of cultural fields (Martindale 1995; Nooy 2002). Each field has its special mechanisms that are responsible for the production of reputation. The autonomy of a cultural field is shown by the independent, internal production of reputation within the field, largely determined by the community's internal system of norms. However, meritocratic reputation can be distorted by a lack of competition, which might be due to excessive hierarchy or centralization within the field (Bourdieu 1985, 1983). Distortion may also result from an external (economic or political) force that restricts the autonomy of the field. For example, the intervention of political power may decouple official and informal reputation in culture.

The emergence of the elite within the cultural field has a generational logic, as new actors take up elite positions. In the meantime, there can be great differences among how these actors use the meritocratic reputation they have acquired through their cultural activity, and whether they use other external resources and forms of legitimation.

Empirical studies about the emergence of the cultural elite focus on two main factors: the distribution of elite positions, and the career trajectories that lead to the elite (Nooy 2002; Verboord 2003). Career trajectories are tightly bound to the institutions of the cultural field; recognition is hierarchical, and guarded by so-called 'gatekeepers', i.e. actors who supervise institutional access (Bielby and Bielby 1994; Foster, Borgatti, and Jones 2011; Hirsch 2000). The production of reputation and the emergence of the elite are the results of interactions between individuals and institutions; career trajectories usually consist of a sequence of institutional positions (Dubois and François 2013; van Dijk 
1999). The institutional representations of reputation also include cultural awards (Anand and Watson 2004; Gemser, Leenders, and Wijnberg 2007; Ginsburgh 2003; Lampel, Lant, and Shamsie 2000). In the long run, acquired reputation creates a solid artistic or scientific canon (Martindale 1995), shaping the whole structure of the cultural field.

Fligstein and McAdam use the concept of strategic action fields to model the process by which a field undergoes restructuration. They study the formation of crises that change existing power relations and the distribution of positions and resources. They find that the stability of fields is most often threatened by crises caused by external shocks. These kinds of shocks create opportunities for groups within the field who want to displace the incumbent elite. If these challengers recognize (or construct) the opportunity hidden in the crisis and are able to act in an innovative and organized way, they may be able to displace the incumbent elite (Fligstein and McAdam 2012).

\section{THE HUNGARIAN CULTURAL ELITE}

According to evidence from earlier elite surveys (Kristóf, 2012), the cultural elite was the most closed and constant elite group in Hungary during the last three decades. Its members could greatly rely on the cultural and social capital that had accumulated in their families. The educational level and occupation of parents and grandparents, as well as the urban (and especially Budapestbased) character of the group were signs of the favorable social status of families.

The cultural elite of the late communist period was composed almost exclusively of male graduates. Researchers of the transition period argued that the selection criteria of the Hungarian economic and cultural elites in the 1980s were rather meritocratic (with the exception of people who openly criticized the communist system). However, the very small share of women in these elite segments challenges the common belief that the period of communist modernization provided women with equal chances at career building. The share of female cultural elite members started to increase only in the second post-communist decade. Although still very low, it more than doubled from its starting level and appeared to be converging to West-European proportions (Table 1). 
Table1 Basic socio-demographic characteristics of the cultural elite

\begin{tabular}{|c|c|c|c|c|}
\hline Cultural elite & 1988 & 1993 & 2001 & 2009 \\
\hline share of female (\%) & 4.8 & 6.3 & 15 & 16.7 \\
\hline mean age (year) & 57.8 & 57.9 & 57.2 & 58.9 \\
\hline share of graduates (\%) & 100 & 98.1 & 98,6 & 98,0 \\
\hline share of white-collar fathers (\%) & 46.6 & 65.4 & 71.7 & 71.8 \\
\hline share of former Communist Party (MSZMP) members & 71.2 & 54.4 & 34.7 & 30.4 \\
\hline
\end{tabular}

Source: Kristóf (2012)

As for education, the high proportion of graduates is a constant in the cultural elite. A university or college degree seems to be a permanent standard. While the cultural elite has become more open to women during the last two decades, it has become more closed in terms of social origin. The share of elite members with white collar fathers increased throughout the whole period. In 1988, the share of blue-collar fathers was above 50 per cent in all segments. This proportion fell dramatically after the system change: the new members clearly came from families of higher status. The cultural elite was affected less by the system change than the political elite, and the share of former Communist Party (MSZMP) members gradually decreased in the first decade of post-communism and halted subsequently. This may have been caused by the permanent presence of a distinguished 'great generation' that could be detected in the political as well as the cultural elite (Kristóf, 2012).

During the whole period, cultural capital was the most important element of the elite status of the cultural elite. Elite universities in Budapest have been especially important in the selection of the cultural elite. In this respect, processes of homogamy and status transmittance could also be observed (Kovách 2011).

In previous studies about the cultural elite, informally influential members of the elite received special focus. I have examined comprehensively those elite members who had the greatest reputation according to other elite members. Reputation was related to age, participation in public life, and artistic activity. Artists were more reputable than scientists. The older they were and the more they published in media not related to their profession, the greater the reputation they had. The reputation of those elite members who engaged in public intellectual activity was also politically determined: leftist and rightist intellectual canons existed side by side (Kristóf 2014, 2013, 2011).

The Hungarian cultural elite is deeply polarized politically and ideologically. 'Culture wars' (Kulturkampf) have been prevalent phenomena after the collapse of the communist regime in 1989. In contrast to politics, the cultural elite was not affected significantly by the regime change; most of its members 'survived' 
the transformation period (Szelényi, Szelényi, and Kovách 1995; Kristóf 2012). Consequently, two parallel narratives dominated Hungarian intellectual life. According to the left-liberal view, the recruitment of the late communist period's cultural elite was primarily meritocratic, and cultural canons settled in the transition period were culturally legitimate. According to right-wing intellectuals, leftist hegemony or dominancy in culture was the product of 40 years of discretional counter-selection, and conservative, nationalistic views remained unfairly repressed by the post-communist elite. According to our earlier studies, reputation-producing mechanisms were indeed functioning more strongly in the leftist intellectual community: most reputable personalities in the cultural elite belonged to that group (Kristóf 2014).

The electoral failure of his first administration in 2002 was attributed by Viktor Orbán, the long-time political leader of the Hungarian right, to the strength of the surviving post-communist elite. In the next decade, he continuously worked to strengthen the economic and cultural embeddedness of his party. Before he finally won the election of 2010, he designated the function of cultural policy in a published and well-cited speech as creating and maintaining the political community. According to the future prime minister, culture is not a distinct sphere, separate from politics. The evaluation of the cultural elite (especially in Eastern Europe) is always based on its political rather than cultural achievement because the latter is always a matter of debate, and there is no universal standard with which to measure it. In the meantime, these debates about values should stay within the narrow circle of the elite, hidden from the broader public. Politics should be ruled by a central field of force undivided by value debates, and 'naturally' representing national values. ${ }^{2}$

After its electoral victory with a two-thirds majority, the Orbán government established a new constitution (Fundamental Law) in 2011. It gave constitutional status to a cultural organization founded by right-wing intellectuals (the Hungarian Academy of Arts). In the next years, the government delegated state functions (cultural financing and awarding policy) to the Academy, by that time established as an autonomous public body. Alongside these delegated functions, the government also assigned generous financial resources. The government's intention to redistribute cultural resources and positions was expressed by Imre Kerényi, government commissioner dealing with symbolic cultural issues:

"Left-liberals must cope with the fact that for them, 'seven lean years' are coming in cultural policy/politics"3

2 http://www.fidesz.hu/hirek/2010-02-17/meg337rizni-a-letezes-magyar-min337seget/. Speech by Viktor Orbán at the Civic Picnic in Kötcse.

3 https://www.youtube.com/watch?v=zKOWRJqDrx0 


\section{CASE STUDY - THE FIELD OF THEATRE}

Before I analyze the elite change in the theatre sphere, I briefly introduce the structure of the Hungarian theatrical field. Hungary basically has a statefunded, company-theatre structure, and all of the larger Hungarian cities have local theatres with a permanent local company. Budapest is the only city with several theatres. Among the theatres, the National Theatre has symbolically privileged status. Besides this basic structure, there are some freelance actors and so-called independent (or 'alternative') companies as well. Independent companies are smaller and do not have their own buildings. Theatres are united in different professional organizations such as the Hungarian Theatre Society, the Hungarian Theatrum Society, and the Independent Association of Performative Arts. Actors from the theatrical field are mostly educated at the University of Theatre and Film Arts in Budapest. There is another graduate-level training institution at the University of Kaposvár (a country town in the South-West of Hungary). As in other cultural spheres, education is especially important in elite recruitment in theatre. A law (the Act on Performative arts, 2008, modified in 2011) even prescribes that theatres should employ a high percentage of actors with graduate-level training. Also, a degree in the Arts is a legal requirement for applying for the position of theatre director. ${ }^{4}$ Consequently, Hungarian theatre directors are not managers, but artist-directors (actors or stage-directors).

Partly because of the permanent company-theatre structure, the functioning of theatres is strongly dependent on state support. They are co-financed by ticket revenue, state support and company tax deductions. Purely market-based productions rarely exist in the 'high cultural' sphere. Theatres are owned and maintained by local municipalities (in the case of a few important institutions, alongside the Ministry of Human Resources), which provide the resources for functioning. Another important actor is the National Cultural Fund (NCF) that supports productions with grants. This support is extremely important for independent companies that do not have a municipal sponsor. NCF is a state fund that is formally led by the Minister of Human Resources. However, representatives of the theatrical sphere are also involved in the grant-awarding procedure as decision-makers.

To define the elite of the field, two overlapping type of elite should be distinguished. The positional elite is composed of the leaders of the field's main institutions: theatres, professional organizations and universities. Membership criteria for the reputational elite is less objective, but professional awards

4 This requirement can be waived if the applicant has 5 years of experience managing an art institution. 
are a good proxy of reputation. The reputational elite is approximated by the recipients of the highest professional awards. ${ }^{5}$

The mechanisms of elite recruitment are twofold. The inner processes and the external social environment of the field are both crucial. To obtain the position of theatre director, professional prestige (based on cultural capital) is required. However, the owners of the theatres are local municipalities, which have the right to appoint directors (along with the Ministry of Human Resources, normally for five years). Given this structure, the appointment of directors has never been just a matter of professional standards. It also depends on the party affiliation of the local government. Prestigious awards are also made by the state. Accordingly, the impact of political power can be clearly observed alongside the influence of the professional referee committees.

\section{CIRCULATION OF THE POSITIONAL ELITE}

The circulation of the positional elite in the theatre sphere started after the 2006 municipal elections that were won by Fidesz, Viktor Orbán's party. Power relations started to change in the sphere, triggered by political change. Since then, most of the country town theatre directors have been replaced (see Table 2).

Table 2. Circulation of theatre directors in permanent theatres in countryside towns

\begin{tabular}{|c|c|}
\hline $1^{\text {st }}$ round of circulation (2006-2009) & $\begin{array}{c}\text { Békéscsaba, Debrecen, Eger, Kaposvár, Kecskemét, } \\
\text { Sopron, Székesfehérvár, Szolnok }\end{array}$ \\
\hline $2^{\text {nd }}$ round of circulation (2010-2014) & Pécs, Tatabánya, Veszprém, Zalaegerszeg \\
\hline No circulation & Miskolc, Nyíregyháza, Győr, Szeged, Szombathely \\
\hline
\end{tabular}

Source: Author's calculation

In 2008, a new professional organization was founded with the name of the Hungarian Theatrum Society. This society aimed to unite 'theatres identifying with the idea of the nation' and was practically formed by the new directors of country town theatres. The president of the society was Attila Vidnyánszky, who was then director of the theatre of Debrecen and later became director of the Hungarian National Theatre in Budapest, and was a key actor in the transformation of the sphere. The Hungarian Theatrum Society, according to both members and rivals, was founded as a kind of counter-organization to

5 Jászai Prize, Kossuth Prize, and the title 'Actor/Actress of the Nation' 
the Hungarian Theatre Society (founded in 1997), and supported the stronger representation of actors and theatres who lean to the political right. Members of the Hungarian Theatrum Society filled 11 of the 16 country town theatre director positions between 2006 and 2014, forming a strong counter-elite in the theatre field.

The media discourse around these theatre director positions almost always refers to 'political appointees', stressing the discrepancy between decisions of the owners and the opinion of the professional referee committees during the application process. The new directors themselves did not usually deny their political commitment. On the contrary, they argued that these positions had always depended on politics, and critics were using double standards against right-leaning actors:

"Yes, back then also, always, they were political appointees. It's only that they would not admit it. Now that it is not their friends who became directors, they of course call them political appointees. Yes, I am a political appointee, but so are they. Like everyone". 6

The members of the old, displaced elite were using a totally different narrative. Their argument was based on the dichotomy of meritocracy vs. political commitment and the denial that there were two political camps fighting in the theatrical sphere.

"Actually, what happened was that, instead of professional considerations, it became more important that 'one of our own' should direct the theatre. So, suddenly new directors appeared for whom political commitment was more important than professional merit"?

The two narratives reflect two different perspectives of the structure of the field. The challenging elite group refers to 'leftist dominancy' as a legacy of communism. They describe the incumbent elite as 'talented, but a product of ideological adverse selection'. Former presidents and leading professors at the University of Theatre and Film are seen as distinguished members of this hegemonic elite group, who can easily reproduce themselves by supervising education. They are exclusive, selective and elitist. Attila Vidnyánszky, who led the challengers, explicitly called this elite group a 'mafia'. By contrast, the narrative of the incumbent elite describes the challengers as power-hungry,

6 Interview with a country town theatre director.

7 Interview with a displaced country town director.

CORVINUS JOURNAL OF SOCIOLOGY AND SOCIAL POLICY VOL. 8 (2017)3S 
resentful, frustrated and - with the exception of Vidnyánszky and perhaps a few others - untalented people, who resent the elite who denied them recognition. Shared by a large part of the reputational elite of theatre makers and leading theatre critics, this second narrative was originally much stronger in the theatrical sphere. However, the group of challengers became institutionalized as a professional organization and, with strong government support, soon became a rival to the older Hungarian Theatre Society. This kind of parallel institutionbuilding is a conventional tool of the government that wishes to stimulate elite change by administrative means if existing institutions and incumbent elite groups are stable. The same technique was used in the case of the Hungarian Academy of Arts (Kristóf 2016). In the field of theatre, the mechanism was also applied to education. After 2010, Vidnyánszky took over the leadership of theatre education at the University of Kaposvár with strong political backing, and attempted to build a kind of counter-institution against the University of Theatre and Film Arts in Budapest. The aim of the institution, according to its new leader, was to build a recruitment base for the new elite group:

"We started to build a university faculty of theatre arts in Kaposvár because I wanted to educate open-minded young artists who have backbone. Graduates who are not driven by conformity, can handle criticism and those critics who think of themselves as kingmakers. I do not question the high standards of the university in Budapest. I only argue that it makes students think in a uniform way. This is what we want to transcend here in Kaposvár". ${ }^{8}$

Despite political support, taking over the faculty in Kaposvár did not go smoothly. Universities function within strict legal rules, therefore the forced transformation of the faculty was accompanied by employment disputes, lawsuits, illegal appointments, and other anomalies. ${ }^{9}$

In the meantime, political attacks on Budapest University remained unsuccessful. In 2013, Imre Kerényi, government commissioner dealing with symbolic cultural issues, was revealed to have talked about the education of actors and other theatre people in a way that generated widespread media attention:

8 Attila Vidnyánszky, Magyar Idők

9 Attila Vidnyánszky was appointed as professor without a doctoral degree. For his appointment, the law on tertiary education had to be modified (a Kossuth prize or an Olympic medal now make up for the lack of a doctoral degree). 
"I think it is very important that some changes should happen at the University of Theatre and Film Arts. If nothing else, a counter-university should be organized (...) If I were the 'vice-king', I would take away the right of teaching actors and all the money from the University of Theatre and Film Arts. (...) A new road should be found; one should fight against this force. This is, actually, a lobby of faggots [sic] ...one should create performances and especially schools against this!"’10

Professors of the University protested in open letters, demanding Kerényi's resignation, and the rector officially inquired if the government was planning to close or reorganize the University. The Minister of Human Resources hurried to declare that there were no such plans, and Kerényi's words were his private opinion. Apart from this statement, no apology was made on behalf of the government; moreover, Kerényi remained in charge as government commissioner.

After Fidesz won the parliamentary elections in 2010, the theatre sphere experienced deep changes through the modification of the Act on Performing Arts. ${ }^{11}$ The original act was created in 2008 in the era of the social-democrat government, and contained the promise of guaranteed state support for independent (or alternative) theatre companies who did not have a permanent theatre building. Independent theatre companies are typically avant-garde, anti-establishment art groups, who often cover socially or politically hot issues in their performances. Their support in the 2008 act was defined as 'at least 10 percent of the state support of the theatre sphere', and it financially institutionalized and acknowledged independent companies as parts of the state support system, causing independent theatre in Hungary to boom. However, after 2010, the relationship between the Orbán-government and the independent theatres soon became strained..$^{12}$ The modification of the Act on Performing Arts in 2011, initiated by Attila Vidnyánszky and his Hungarian Theatrum Company, abolished the guarantee of support and thus caused significant offence to independent troupes, both financially and symbolically. Their situation became precarious and unpredictable; some years they did not even get the support which had been promised.

10 https://www.youtube.com/watch?v=DPRXCdFxW18

$11 \mathrm{http}: / /$ mkogy.jogtar.hu/?page=show\&docid=a1100086.TV

12 As Béla Pintér, leader of the most popular independent theatre company, famously put it: "The previous government gave us money, this one gives us a theme." Most recently, this theme involved covering well-known gossip about the family life of a Fidesz politician and his allegedly lesbian wife. 
Regarding the situation of company-theatres, positional elite change continued. The most important change concerned the director of the National Theatre. This position, appointed by the government, had always been a target of political debates as a symbolic position that represented the traditions and values of Hungarian culture. After 2008, the National Theatre was directed by Róbert Alföldi, a reputable actor and stage director, who was heavily attacked in Parliament by the far-right party Jobbik during his term because of his alleged homosexuality and left-liberal political views and artistic concepts. MPs of the ruling Fidesz party rejected these attacks, and the cultural government let the director complete his official mandate. Afterwards, he was nevertheless replaced by Attila Vidnyánszky, leader of the new, challenging elite group. Vidnyánszky was also an internationally renowned director, whose appointment more or less followed the same process as Alföldi's assignment (with a tender predetermined by the actual government). However, Alföldi's theatre was very successful, in terms of both critical reception and ticket sales, thus his replacement induced a major cultural scandal which went beyond the theatre sphere. Several foreign theatre companies (e.g. the Burgtheater in Vienna) stood up in support of the displaced director, and the domestic theatre audience queued up for tickets as a political demonstration.

In 2010, Fidesz also won the upcoming municipal elections, and Budapest elected a Fidesz party mayor and local government. Ever since, when a theater director position has been tendered, it has attracted widespread media attention. Besides the National Theatre, the appointment of another theatre director sparked a reaction from international media: the situation involved the director of Újszínház, an otherwise rather insignificant downtown theatre in Budapest. To replace the incumbent director, the mayor of Budapest appointed György Dörner, an actor known for his far-right opinions. However, Dörner was not a member of the newly formed counter-elite that was institutionalized in the Hungarian Theatrum Society, and his appointment was an isolated incident among the theatres of Budapest. In successful and reputable theatres (e.g. Katona, Örkény, Radnóti, Vígszínház) the municipality usually supported incumbent directors or their appointed successors (see Table 3).

Table 3 Circulation of theatre directors in Budapest

\begin{tabular}{|c|c|}
\hline circulation 2010-2014 & National Theatre, József Attila, Újszínház \\
\hline No circulation & Katona, Örkény, Radnóti, Vígszínház \\
\hline
\end{tabular}

Source: Author's calculation

According to the interviewees, the municipality of Budapest has affirmed the status quo in the capital: 
"It is interesting that the large Budapest theatres are holding on. Probably there is a limit that cannot be crossed. It seems to some extent that there are places, like Katona or Örkény, where no one applies for the position [against the incumbent director] and therefore it is clear that those theatres will be left standing, while it is clear that most theatres in the countryside slowly fell into someone else's hands".13

With this Budapest-countryside division, the circulation of the positional theatre elite seems to have become limited. The new elite obtained positions in the countryside, at the highest positions in the National Theatre, and also in the referee boards of the National Cultural Fund and the Theatre Art Board in the Ministry of Human Resources, which has control over state grants distributed in tenders.

\section{THE REPUTATIONAL ELITE}

Cultural awards are institutional markers of reputation. Moreover, state awards are also acknowledgements by political power of cultural achievements. The more prestigious the state award, the more present are political considerations in the selection of nominees. The highest state award for arts in Hungary is the Kossuth prize. One level below, the Jászai prize represents the highest award dedicated especially to actors. The majority of award-winning actors cannot really be categorized publicly by their political affiliation because they do not take part in public debates or cultural politics. Still, many artists (first of all, Attila Vidnyánszky) who had earlier stood with Fidesz (e.g. in electoral campaigns) received the Kossuth award after 2010. However, this did not cause much tension in the field because he was chosen not due to party loyalty, but also cultural merit (e.g. he had already received the Jászai award). Members of the incumbent elite already had their Kossuth awards before Fidesz gained power in 2010. Members of the new elite group usually received their Jászai awards earlier, too. If not, they got them after 2010. It seems that, for theatre directors, this award is a must (by now, all the newly appointed country town directors have received one). Nevertheless, the director of one of the critically most sucessful Budapest theatres (Pál Mácsai) also got a Kossuth award from the Orbán-government, despite his critical attitude toward the government's cultural politics.

13 Interview with the dramaturge of an independent art company. 
As far as reputation markers not attached to the state are concerned, there has been much more conflict. The old and new elite groups are fighting hard for reputation, turning the most prestigous annual theatre festival (POSZT) into a battlefield. Earlier, the challenger group had criticised the fact that Vidnyánszky's plays had never been selected for inclusion on the festival program before 2010, although he was an internationally renowned stage director. Their innovative solution was to propose a change in the selection process. Since 2012, one selector is nominated by the Hungarian Theate Society and another by the rival Hungarian Theatrum Society. Scandals around the selection of the jury resulted in a boycott of the festival by some theatres in 2015. In that year, Attila Vidnyánszky won four awards. In the following year, the two societies agreed to nominate members of the festival jury by parity, which made the new status quo explicit. Curiously, the Grand Prix of the latest festival went to a country town theatre (Kecskemét) that was led by a director closely attached to the Fidesz party. In the meantime, the winning play was directed by a stage diretor who was a distinguished member of the former reputational elite.

In March 2017, a public opinion poll $(\mathrm{N}=500)$ surveyed the reputation of some members of the Hungarian cultural elite. Among others, the two latest directors of the National Theatre were included in the survey (see Table 4). Both of them are emblematic figures in the theatre sphere, representing the two competing elite groups.

Table 4 Do you consider this person to be an outstanding personality in Hungarian culture? (Percentage of YES answers according to party preference)

\begin{tabular}{|c|c|c|c|c|}
\hline & \multicolumn{4}{|c|}{ Party preference } \\
\hline & Fidesz & $\begin{array}{c}\text { Leftist opposition } \\
\text { parties(MSZP, DK,PM, } \\
\text { Együtt, LMP) }\end{array}$ & $\begin{array}{c}\text { Rightist opposition } \\
\text { party (Jobbik) }\end{array}$ & Total \\
\hline $\begin{array}{c}\text { Róbert Alföldi (director of } \\
\text { the National Theatre, } \\
\text { 2008-2013) }\end{array}$ & 56 & 52 & 41 & 51 \\
\hline $\begin{array}{c}\text { Attila Vidnyánszky (director } \\
\text { of the National Theatre, } \\
\text { 2013-) }\end{array}$ & 39 & 8 & 8 & 25 \\
\hline
\end{tabular}

Source: Representative survey ordered by the Centre for Social Science, conducted by Závecz Research

In the category of outstanding cultural personality, former director Róbert Alföldi received ten times more votes than Vidnyánszky. This is mainly because he is also a very well-known actor (who also performs on television), while Vidnyánszky is 'only' a stage director besides directing the National Theatre. 
Yet, according to the analysis of media discourse, Alföldi's reputation was boosted very much by his displacement from his position: the Orbán government successfully made him a 'martyr' and an iconic figure of the political left. In the meantime, Vidnyánszky's takeover of the National Theatre from Alföldi decreased his professional reputation, at least among theatre critics. The reputation of the two individuals in the eyes of a wider audience is also different, as can be seen from Table 4. Alföldi's reputation outside the cultural elite is not really influenced by party preferences (even 41 percent of far-right Jobbik voters considers him culturally outstanding). Meanwhile, Vidnyánszky's reputation is determined by party preferences: only Fidesz voters regard him highly.

\section{CONSEQUENCES OF THE CHANGE OF ELITES IN THE CULTURAL FIELD}

In the Hungarian field of theatre, the last ten years have seen the redistribution of cultural positions and resources, and the construction of a new, politically motivated elite. This process happened through several channels and institutions. Perhaps the most visible process has been the replacement of a large part of the positional elite. The positions of theatre directors are under direct political control due to state ownership. Therefore, they can be brought relatively easily under political patronage. Consequently, the problem of 'political appointees' has continued to occur - and not only in the symbolically important institutions, but in almost all cases. The real crisis was caused by the sudden shift in the political power balance that provoked many positional changes, all in the same direction and within a short time period. However, such circulation would not have been successful without parallel processes of institution-building (professional organization, education) by the challenger group of the theatre elite. This group also gained an important role in awarding prizes and tender money. The unquestionable leader of this group, Vidnyánszky, accumulated significant power in the field as the multi-positional leader of the National Theatre, Hungarian Theatrum Society and vice-rector of the University of Kaposvár. He has a say in theatre director application processes as well.

However, there is a significant difference between Budapest and the countryside as regards elite circulation. Countryside theatres, given their monopolistic position in their towns, are generally less specialized than theatres in the capital. In the absence of a distinct artistic character, directors are easy to replace. By contrast, for the Budapest theatres hardly any applicants desired to compete against brand-shaping, prominent incumbent directors. Another difference concerns the local importance of theatres. In smaller cities, the popularity and 
ticket sales of local theatres are more important for local politicians than in the capital. In some cases, this consideration trumps political affiliations. For example, a 'political appointee' failed financially for two years in the city of Györ, and was then replaced by a politically neutral candidate.

A clear limitation to further elite circulation in the theatre sphere is 'reputation shortage'. Recently, there have been no competent and politically loyal applicants to elite positions. In the latest case to generate widespread media attention, the incumbent director in the city of Szombathely was a highly reputed, elderly actor-stage director (Tamás Jordán) who had been awarded the Kossuth prize and been the director of the National Theatre between 2003 and 2008. Moreover, he founded the theatre in Szombathely, where there was no theatre company before, and won festival prizes for the theatre during his mandate. The other applicant was a film director with no reputational markers, but who enjoyed the support of Attila Vidnyánszky. The whole theatre company stood behind the incumbent director and local newspapers strongly attacked the other applicant, who chose to step down. Still the local municipality would not appoint the incumbent, who was now the sole candidate. Famous actors petitioned the local municipality and a few thousand people demonstrated in front of the town hall. Finally, Jordán was given a temporary mandate for a year, after which the municipality plans to open a new tender.

What are the consequences of the elite circulation on the structure of the theatre field? Positional elite change seems to have been successful. However, it is more difficult to change mechanisms that produce reputation. While the positional elite can be easily displaced, the construction of professional reputation is slow and difficult.

At the beginning of this paper, I emphasized the role of institutional cultural capital in the recruitment of the cultural elite. In the case of the theatre elite, the University of Theatre and Film Arts is a crucial hegemonic institution. Without its political control, elite recruitment cannot be controlled. The university repelled several political attacks, thus challenger elite members started to build up a counter-institution, which may be a slow but culturally accepted way of constructing their own reputational elite. (They have even deliberated starting a new graduate training program for theatre critics, which clearly shows their aspirations.) However, the cumulative advantages of the Budapest University make the outcomes of these attempts ambiguous.

In my case study, I examined how politically motivated elite circulation happened in the Hungarian theatre sphere. The same direction of change is observable in other cultural fields as well. The governing elite is attempting to rewrite cultural canons and occupy existing elite positions in the cultural field. In other cases, they have founded new cultural institutions and positions, as well as created or strengthened parallel/alternative structures alongside existing ones 
in the cultural field in order to elicit elite change. Changing the financial system of culture in favor of new loyal groups is also part of this process.

However, newly placed elite members do not represent any kind of cultural or ideological unity. The criterion for their recruitment is simply that they should not be attached to the old elite. They have to demonstrate their political loyalty to obtain their appointments, but strong ideological identification is not required. Interviews undertaken for this case study support earlier findings (Kristóf 2014) that, despite strong polarization and political division in the cultural elite, aesthetic and artistic differences cut across political preferences. Therefore, the aesthetic concepts of newly appointed directors are almost as heterogeneous as those of the earlier elite. ${ }^{14}$ Once new cultural elite members have shown loyalty, they are not controlled directly by the political elite. Instead, they enjoy wide autonomy in managing their institutions and realizing their artistic concepts freely, whether in a dilettantish or professional way. ${ }^{15}$

Besides being political appointees, new members of the elite come from the cultural field, with some amount of accumulated cultural capital. Once in position, they usually legitimize themselves by following the norms and logic of the cultural field, which often leads to the strengthening of previous cultural structures, not their elimination. This situation can be observed both in their decisions about theatre management and awarding policies. One interviewee from the case study shed light on these mechanisms as follows:

"What happened was the following: once a nice rightist guy was appointed as theatre director, he could do several things. One, like P. B., can go for trash and the audience will always like it. The theatre is successful. Another, like B. B., says that his is the 'theatre of hope' and he will not show people what is real, but give them hope. The theatre is not successful. Or, one can do what P. Cs. does at Kecskemét. He said: 'okay, I supported Orbán in the electoral campaign, I got my reward, now I will make theatre! Now I will show Kecskemét that I can make good theatre.' Of course, for this he needs to know what good theatre is. And he knows that. And then he invites the famous liberal stage director, hires young talent, and the theatre starts to improve step by step. There are several others who chose this path. Not just one. Not only him. In a way, this has already started silently, from the bottom up".

14 For example, Vidnyánszky's avant-garde directions do not really meet the conservative tastes of his politically sympathetic audience, which has resulted in poor ticket sales (Hegedüs 2015).

15 However, I have identified a case in which a politician directly influenced artistic repertoire. When the new, far-right(ish) director of Újszínház wanted to open the season with an openly anti-Semitic drama (István Csurka's The Sixth Coffin), the mayor of Budapest expressed his objections. Although theoretically the municipality as the owner of the theatre does not have the right to influence repertoire, the controversial play was eventually not presented. 
The theatre sphere is a cultural field in which politics can relatively easy interfere to bring about positional elite change. However, it cannot easily bring about substantive change. This process shows the limited efficacy of political patronage in the cultural elite. At the end of the studied period, a new status quo seems to be emerging between old and new elite groups. However, given that culture is strongly dependent on the resources of political power, the status quo is still at the mercy of political change.

\section{REFERENCES}

Anand, N., and Mary R. Watson (2004), "Tournament Rituals in the Evolution of Fields: The Case of the Grammy Awards." The Academy of Management Journal Vol. 47, No 1, pp. 59-80. http://dx.doi.org.10.2307/20159560.

Bielby, William T., and Denise D. Bielby (1994), “'All Hits Are Flukes': Institutionalized Decision Making and the Rhetoric of Network Prime-Time Program Development." American Journal of Sociology Vol. 99, No 5, pp. 1287-1313.

Bourdieu, Pierre (1983), "The Field of Cultural Production, or: The Economic World Reversed." Poetics Vol. 12, No. 4, pp. 311-56. doi:10.1016/0304422X(83)90012-8.

. (1985), "The Market of Symbolic Goods." Poetics Vol. 14, No. 1, pp. 13-44. http://dx.doi.org.10.1016/0304-422X(85)90003-8.

. (1996), The Rules of Art: Genesis and Structure of the Literary Field.

Stanford University Press.

Bozóki, András (2015), "Broken Democracy, Predatory State and Nationalist

Populism." In The Hungarian Patient: Social Opposition to an Illiberal Democracy, by Peter Krasztev and Jon Van Til. Central European University Press.

Dijk, Nel van (1999), "Neither the Top nor the Literary Fringe: The Careers and Reputations of Middle Group Authors." Poetics Vol. 26, No. 5, pp. 405-21. http://dx.doi.org.10.1016/S0304-422X(99)00016-9.

Dubois, Sébastien, and Pierre François (2013), "Career Paths and Hierarchies in the Pure Pole of the Literary Field: The Case of Contemporary Poetry." Poetics Vol. 41, No. 5, pp. 501-23. http://dx.doi.org.10.1016/j.poetic.2013.07.004.

Fligstein, Neil, and Doug McAdam (2012), A Theory of Fields. 1 edition. New York: Oxford University Press.

Foster, Pacey, Stephen P. Borgatti, and Candace Jones (2011), "Gatekeeper Search and Selection Strategies: Relational and Network Governance in a 
Cultural Market." Poetics Vol. 39, No. 4, pp. 247-65. http://dx.doi.org.10.1016/j. poetic.2011.05.004.

Gemser, G., M. A. A. M. Leenders, and N. M. Wijnberg (2007), "Why Some Awards Are More Effective Signals of Quality Than Others: A Study of Movie Awards." Journal of Management Vol. 34, No. 1, pp. 25-54. http:// dx.doi.org.10.1177/0149206307309258.

Ginsburgh, Victor (2003) "Awards, Success and Aesthetic Quality in the Arts." Journal of Economic Perspectives Vol. 17, No. 2, pp. 99-111. http://dx.doi. org.10.1257/089533003765888458.

Hegedüs, Márton (2015), “Nemzeti? Színház. A Nemzeti Színház Szerepe a Kultúrpolitikában." Tudományos Diákköri Dolgozat, Budapesti Corvinus Egyetem.

Hirsch, Paul M. (2000), "Cultural Industries Revisited." Organization Science Vol. 11, No. 3, pp. 356-61.

Kovách, Imre, ed. (2011), "Elitek a Válság Korában." Budapest: MTA PTI MTA ENKI - Argumentum.

Kristóf, Luca (2011), "Politikai nézetek és reputáció az értelmiségi elitben." Politikatudományi Szemle Vol. 20, No. 2, pp. 83-105.

(2012), "What Happened Afterwards? Change and Continuity in the Hungarian Elite between 1988 and 2009." Historical Social Research Vol. 37, No. 2, pp. 108-22.

(2013), "Reputation among the Hungarian Intellectual Elite." In New Public Spheres: Recontextualizing the Intellectual, eds. Christiane Timmerman, Sara Mels, Peter Thijssen, and Walter Weyns. Ashgate Publishing, Ltd.

Budapest: MTA TK - L'Harmattan.

-(2015), “A Politikai Elit.”In A Magyar Politikai Rendszer-Negyedszázad Után, edited by András Körösényi, pp. 59-84. Budapest: Osiris.

Lampel, Joseph, Theresa Lant, and Jamal Shamsie (2000), "Balancing Act: Learning from Organizing Practices in Cultural Industries." Organization Science Vol. 11, No.3, pp.263-69. http://dx.doi.org.10.1287/orsc.11.3.263.12503. Lengyel, György (2014), "Elites in Hard Times: The Hungarian Case in Comparative Conceptual Framework." Comparative Sociology Vol. 13, No. 1, pp. 78-93. http://dx.doi.org.10.1163/15691330-12341292.

Martindale, Colin (1995), "Fame More Fickle than Fortune: On the Distribution of Literary Eminence." Poetics Vol. 23, No. 3, pp. 219-34. http://dx.doi. org.10.1016/0304-422X(94)00026-3.

Nooy, Wouter de (2002), "The Dynamics of Artistic Prestige." Poetics Vol. 30, No. 3, pp. 147-67. 
Pareto, Vilfredo (1942), The Mind and Society: A Treatise on General Sociology. Edited by Arthur Livingston. Harcourt, Brace and Co.

Szelényi, Szonja, Iván Szelényi, and Imre Kovách (1995), “The Making of the Hungarian Postcommunist Elite: Circulation in Politics, Reproduction in the Economy." Theory and Society Vol. 24, No. 5, pp. 697-722.

Verboord, Marc (2003), "Classification of Authors by Literary Prestige." Poetics Vol. 31, No. 3, pp. 259-81. http://dx.doi.org.10.1016/S0304-422X(03)00037-8. 
